\title{
Vitamin E Profiles and Triacylglycerol Molecular Species of Colored Rice Bran Cultivars at Different Degree of Milling
}

\author{
Hiromi Yoshida ${ }^{1}$, Mika Kanamori ${ }^{1}$, Naoko Yoshida ${ }^{2}$, Yuka Sakamoto ${ }^{1}$, \\ Isoko Kuriyama ${ }^{1} \&$ Yoshiyuki Mizushina ${ }^{1,3}$ \\ ${ }^{1}$ Department of Nutritional Science, Kobe Gakuin University, Kobe, Hyogo 651-2180, Japan \\ ${ }^{2}$ Department of Stem Cell Pathology, Kansai Medical University, Hirakata, Osaka 573-1010, Japan \\ ${ }^{3}$ Cooperative Research Center of Life Sciences, Kobe Gakuin University, Kobe, Hyogo 650-8586, Japan \\ Correspondence: Hiromi Yoshida, Department of Nutritional Science, Kobe Gakuin University, Nishi-ku, Kobe, \\ Hyogo 651-2180, Japan. Tel: 81-78-974-1551. E-mail: yoshida@nutr.kobegakuin.ac.jp
}

Received: August 22, 2013 Accepted: October 25, 2013 Online Published: November 20, 2013

doi:10.5539/jfr.v2n6p106 URL: http://dx.doi.org/10.5539/jfr.v2n6p106

\begin{abstract}
The objective of this study was to evalute the tocochromanol distributions, lipid components and molecular species of triacylglycerols (TAG) in three colored rice bran cultivars. The dominant tocochromanol were $\gamma$-tocotrienol, $\alpha$-tocopherol and $\alpha$-tocotrienol with smaller amounts of $\gamma$-tocopherol, $\delta$-tocopherol and $\delta$-tocotrienol. These lipids comprised mainly TAG (78.0-81.6 wt \%), free fatty acids (FFA: 5.6-8.8 wt\%), and phospholipids (PL: 6.3-7.0 wt\%), while other components were present in minor proportions $(0.4-2.3 \mathrm{wt} \%$ ). Sixteen different TAG molecular species were detected and quantified by successive applications of $\mathrm{AgNO}_{3}-\mathrm{TLC}$ and GC. The major TAG molecular species were $\mathrm{SM}_{2}(6.1-9.8 \%), \mathrm{S}_{2} \mathrm{D}$ (4.8-7.3\%), $\mathrm{M}_{3}(16.4-18.7 \%)$, SMD (6.2-9.2\%), $\mathrm{SD}_{2}$ (6.5-9.5\%), SMT (6.3-7.7\%), $\mathrm{M}_{2} \mathrm{D}$ (12.3-15.5\%.), $\mathrm{MD}_{2}(8.4-10.4 \%)$, SDT (4.3-5.4\%) and $\mathrm{D}_{3}$ (10.2-15.2\%) (where S, M, D, and T denote saturated FA, monoene, diene, and triene, respectively). The results showed that colored rice bran lipids contain large amounts of nutraceutical with proven positive health effects.
\end{abstract}

Keywords: bran lipids, colored rice, molecular species, tocopherol homologues, triacylglycerols

Abbreviations: FFA, free fatty acids; GC, gas chromatography; HMRB, half-milled rice bran; HPLC, high-performance liquid chromatography; PL, phospholipids; TAG, triacylglycerols; TLC, thin-layer chromatography; WMRB, well-milled rice bran

\section{Introduction}

Rice (Oryza sativa L.) constitutes the world's principal source of food (Yadav \& Jindal, 2001). Rice is the stable food of Asia, where $90 \%$ of the world's rice crop is produced and consumed. Rice is commonly consumed as milled or white rice, which is produced by removing the hulled and bran layers of the rough rice kernel in dehulling and milling processes, respectively. The colored grain are caused by anthocyanins pigment that gives the dulled rice a red and brownish red color in red rice or a dark purple color in black rice (Oki et al., 2002). These two types of rice were gaining popularity in Japan as functional food and often mixed with rice to enhance the color, flavor, and nutritional value (Itani \& Ogawa, 2004). Moreover, rice grain quality is an important economic trait that influences rice production in many rice-producing areas. Although the fat or oil in rice grain is low (i.e., 2-3\%) and is concentrated in the germ and bran, it is a key determinant of the processing and cooking quality of rice (Zhou et al., 2002a). For instance, the surface lipid content has been thought to be an indication of the degree of milling (Siebenmorgan, Matsler, \& Earp, 2006). The milling efficacy is measured by degree of milling. The amount of bran remaining on the rice kernel after milling affects rice quality, appearance, and texture and rice is thus milled to the end-use preference of different consumers (Perdon et al., 2001; Saleh \& Meullenet, 2007). In addition, rice lipid, which frequently forms complexes with starch granules, was shown to affect starch gelatinization, water availability to starch, and rice swelling and thus influences the eating and cooking qualities of rice (Champagne, Marshall, \& Goynes, 1990; Marshall, Norma, \& Goynes, 1990). Besides dietary consumption, the unique health benefits of rice fat, which includes many unsaturated fatty acids, has drawn much attention (Jennings \& Akoh, 2009). A number of studies have shown that rice bran oil reduces the harmful cholesterol (low-density lipoprotein) without affecting the good cholesterol (high-density lipoprotein) in 
plasma (Sugano \& Tuji, 1997; Wilson et al., 2007). In addition, rice bran oil, which is rich in tocotrienol (Vitamin E), has anti-cancer and anti-radiation effects (Wilson et al., 2007). A combination of tocopherols and tocotrienols, preferably from natural sources, has been suggested to be an essential part of a diet preventing Alzhaimer disease (Morris et al., 2005) or to be aiding in the treatment of Parkinson's syndrone (Itoh et al., 2006). On the other hand, some reports have shown that the hydrolysis and oxidation of rice fat are responsible for rice aging and deterioration of grain flavor during storage, and low-oil rice cultivars are more suitable for storage (Zhou et al., 2002b).

Several studies on lipid fractions of rice brans have been published (Taira et al., 1988; Jennings \& Akoh, 2009; Przybylski et al., 2009). However, to the best of our knowledge, no data have been reported on the vitamin $\mathrm{E}$ homologues, lipid components and fatty acid compositions of colored rice bran cultivars at different degrees of milling. Therefore, the aim of this study was to investigate the tocochromanol distributions and the molecular species of triacylglycerols (TAG) obtained from the three colored rice bran cultivars, based on differences in the degrees of milling.

\section{Materials and Methods}

\subsection{Raw Materials}

Commercially mature rice seeds used were from the three different colored Japanese cultivars: black (Okunomurasaki), red (Beniroman) and green (Midorimochi) harvested in September 2012 at the same district (Takaichigun, Nara Predecture) of Japan. These colored rices were purchased from regional alliance center for industrial technology at Asuka district of Nara prefecture. Black and red rices were nonglutinous rice, and green rice was a glutinous rice. For analysis, seeds were selected for uniformity based on seed weight of 19.8-21.1 mg for black, 20.6-21.7 mg for red and 17.2-18.4 mg for green, respectively. Rices of each cultivar were packed in polyethylene bags under nitrogen gas and placed in a stainless-steel container at $-35^{\circ} \mathrm{C}$ until analysis.

\subsection{Chemicals and Reagents}

All chemicals were of analytical grade (Wako Pure Chemical Inc., Osaka, Japan). TLC-plates were purchased from Merck (Darmstadt, Germany). Standard mixture for TLC, containing monoacylglycerols, diacylglycerols, free fatty acids (FFA), triacylglycerols (TAG), steryl esters and hydrocarbons, was purchased from Wako Pure Chemical. Standard TAG (glyceryl trimyristate, glyceryl tripalmitate, glyceryl tristearate, glyceryl trioleate, glyceryl trilinoleate and glyceryl trilinolenate) was procured from Sigma-Aldrich Co. (St. Louis, Mo, USA). Vitamin E homologues $(\alpha, \beta, \gamma$ and $\delta)$ were acquired from Sigma-Aldrich Co. All tocopherols were of the D-form $(R R R-)$, and their purities were better than $98.8 \%$. Fatty acid methyl esters (FAME) standards (F \& OR mixture \#3) were obtained from Altech-Applied Science (State College, PA, USA). The internal standards, pentadecane and methyl pentadecanoate, were purchased from Merck, and then $100 \mathrm{mg}$ of each was dissolved in $n$-hexane $(20 \mathrm{ml})$. Boron trifluoride $\left(\mathrm{BF}_{3}\right)$ in methanol (14\%; Wako Pure Chemical Inc., Osaka, Japan) was used to prepare the FAME.

\subsection{Lipid Extractions}

Rice bran of each cultivar (500 g) was milled using a domestic miller (BR-CA25, Zojirushi Ltd., Osaka, Japan). Before extraction, each bran prepared from half-milled rice and well-milled rice was defined as HMRB and WMRB, respectively. The degree of milling was $5 \%$ milling for HMRB and $10 \%$ for WMRB. Total lipids were extracted from $20 \mathrm{~g}$ of bran in $300 \mathrm{ml}$ chloroform/methanol $(2: 1, \mathrm{v} / \mathrm{v})$ with vigorous shaking for $15 \mathrm{~min}$ at $0{ }^{\circ} \mathrm{C}$ three times, following the Folch procedure (Folch et al., 1957). The extracted lipids were weighed to determine the lipid content of the rice brans and then transferred to a $25-\mathrm{ml}$ brown-glass volumetric flask with chloroform/methanol $(2: 1, \mathrm{v} / \mathrm{v})$, flushed by nitrogen, and stored in the dark at $-35^{\circ} \mathrm{C}$ until further use.

\subsection{Tocochromanol Analysis}

Determinations of tocochromanols were performed by HPLC according to the methods reported previously (Yoshida, Tomiyama, \& Mizushina, 2010). An aliquot (10 $\mu$ l) from this sample solution was subjected to HPLC analysis, and the amount of each tocochromanol was determined with a fluorescence detector (Shimazdu RF-10 AXL, Kyoto, Japan) as previously reported (Yoshida, Tomiyama, \& Mizushina, 2010).

\subsection{Lipid Analysis}

According to the previous procedure (Yoshida et al., 2013), total lipids were fractionated by TLC into nine fractions using a solvent system of $n$-hexane/diethyl ether/acetic acid $(80: 20: 1, \mathrm{v} / \mathrm{v} / \mathrm{v})$. Bands corresponding to hydrocarbons, steryl esters, TAG, unknown, FFA, 1,3-diacylglycerols, 1,2-diacylglycerols, monoacylglycerols and PL were scraped into separate test-tubes. Methyl pentadecanoate $(10-100 \mu \mathrm{g})$ from a standard solution $(5$ 
$\mathrm{mg} / \mathrm{ml})$ was added to each tube as the internal standard, except that pentadecane $(10 \mu \mathrm{g})$ was used as the internal standard for hydrocarbons analysis. FAME was prepared by heating with silica gel for 30 min at $80{ }^{\circ} \mathrm{C}$ in $\mathrm{BF}_{3} /$ methanol (Kitts et al., 2004). The FAME was quantified by gas chromatography (GC, 14B GC Shimadzu) equipped with a hydrogen flame ionization detector (FID) at $350{ }^{\circ} \mathrm{C}$ and a polar capillary column (ULBO HE-SS-10 for FAME, fused silica WCOT [no. PSC5481], cyanopropyl silicone, $30 \mathrm{~m}$ x $0.32 \mathrm{~mm}$ i.d.; Shinwa Chem. Ind., Ltd., Kyoto, Japan) at a column temperature of $180{ }^{\circ} \mathrm{C}$. The component peaks were identified and compared against that of the standard FAME as a previously described method (Yoshida et al., 2013). The detection limit was $0.05 \mathrm{wt} \%$ of total fatty acids for each FAME in the FAME mixture, and the results are expressed as $\mathrm{wt} \%$ of total FAME. The other GC conditions were as in the previously described (Yoshida et al., 2010).

\subsection{TAG Analysis}

The TAG isolated by TLC was directly analyzed by GC according to a previously described method (Molkentin, 2007), using the Shimadzu Model-14C GC equipped with a hydrogen FID. Helium was used as the carrier gas at a flow rate of $50 \mathrm{ml} / \mathrm{min}$. The injection port and the FID were set at 320 and $350{ }^{\circ} \mathrm{C}$, respectively. The oven temperature was programmed to increase from an initial temperature of $285^{\circ} \mathrm{C}(5 \mathrm{~min}$ hold $)$, rising to $320^{\circ} \mathrm{C}$ at a rate of $2{ }^{\circ} \mathrm{C} / \mathrm{min}$, which was held isothermally $\left(320^{\circ} \mathrm{C}\right)$ for $20 \mathrm{~min}$. TAG peaks were identified by co-chromatography with known standards. Peak areas were calculated by the addition of a known weight (50 $\mu \mathrm{g})$ of glyceryl trimyristate as the internal standard, using an electronic integrator (Shimadzu C-R6A).

\subsection{TAG Species Composition}

Molecular species separation from total TAG was carried out by $\mathrm{AgNO}_{3}$-TLC (Bilyk et al., 1991). TAG classes differing in unsaturation were isolated by $\mathrm{AgNO}_{3}-\mathrm{TLC}$ using 1.2-2.8\% (v/v) methanol in chloroform, depending on the degree of unsaturation (Jham et al., 2005). The plates were streaked with 10-15 mg TAG using the microsyringe, developed with $1.2 \%$ (v/v) methanol in chloroform, and $\mathrm{S}_{3}, \mathrm{~S}_{2} \mathrm{M}, \mathrm{SM}_{2}, \mathrm{~S}_{2} \mathrm{D}, \mathrm{M}_{3}, \mathrm{SMD}$ and $\mathrm{SD}_{2}$ were easily separated. Furthermore, TAG molecular species such as SMT, $\mathrm{M}_{2} \mathrm{D}, \mathrm{MD}_{2}, \mathrm{SDT}, \mathrm{D}_{3}, \mathrm{MDT}, \mathrm{M}_{2} \mathrm{~T}, \mathrm{MT}_{2}$, and $\mathrm{D}_{2} \mathrm{~T}$ (where $\mathrm{S}, \mathrm{M}, \mathrm{D}$ and $\mathrm{T}$ denote saturated FA, monoene, diene, and triene, respectively) were separated by developing the plate with $2.8 \%(\mathrm{v} / \mathrm{v})$ methanol in chloroform. Each TAG subfraction was identified by comparison with the $R_{\mathrm{f}}$-values of the TAG standard. Each band was recovered from the plate by extraction with $3.0 \%$ aqueous $\mathrm{HCl}$ in the purified diethyl ether, and then the solvent was then vaporized under a gentle stream of nitrogen. Methyl pentadecanoate $(10-50 \mu \mathrm{g})$ of the standard solution $(2-10 \mu \mathrm{l} ; 5 \mathrm{mg} / \mathrm{ml})$ was added to each tube as the internal standard. After methylation of all TAG sufractions, the relative amount of each TAG fraction was quantified by $\mathrm{GC}$ as described in the preceding paragraphs. The other conditions were as previously described (Yoshida et al., 2010).

\subsection{Data Analysis}

Data in this study were expressed as means \pm SD for at least three independent experiments. Differences between the means of individual groups were assessed by one-way analysis of variance and Tukey's multiple range test using the SAS statistical software package (SAS, Cary, NC, USA). Differences were considered significance at $P$ $<0.05$.

\section{Results and Discussion}

\subsection{The Content of Brans and Their Lipids in Colored Rices}

The bran content of the rice black, red and green cultivars $(500 \mathrm{~g})$ were $41.9 \mathrm{~g}(8.4 \%), 29.6 \mathrm{~g}(5.9 \%)$ and $19.4 \mathrm{~g}$ (3.9\%) from the HMRB, and then $76.7 \mathrm{~g}(15.3 \%), 59.2 \mathrm{~g}(11.8 \%)$ and $37.5 \mathrm{~g}(7.5 \%)$ from the WMRB for black, red and green cultivars, respectively. The bran contents of the HMRB and WMRB were significantly $(P<0.05)$ different among the three cultivars. On the other hand, the lipid contents obtained from these rice brans was $7.4 \mathrm{~g}$ (17.7\%), $5.4 \mathrm{~g}(18.2 \%)$ and $4.8 \mathrm{~g}(24.7 \%)$ from the HMRB and then $11.0 \mathrm{~g}(14.4 \%), 8.9 \mathrm{~g}(15.1 \%)$ and $7.9 \mathrm{~g}$ $(21.1 \%)$ from the WMRB, for black, red and green cultivars. The percentage of lipid contents was significantly $(P<0.05)$ higher in the HMRB than in the WMRB, and was in the rank order: green $>$ red $>$ black in both brans. Therefore, the lipids may be higher in the outer bran layer than in the interior bran layer.

\subsection{Tocochromanol Contents in the Rice Bran Cultivars}

The lipid content of the rice samples analyzed ranged from 2.2 to $3.7 \%$ (data not shown). When comparing tocochromanols among the three cultivars as shown in Table 1, the individual amounts was significantly $(P<$ 0.05) lower in the green brans than in the black or red brans. With a few exceptions, the predominant tocochromanol forms in rice bran cultivars were $\gamma$-tocotrienol, $\alpha$-tocotrienol, and $\alpha$-tocopherol. The content of $\gamma$-tocotrienol ranged from 325 to $593 \mathrm{mg} / \mathrm{kg}, \alpha$-tocotrienol was found between 93.6 and $293 \mathrm{mg} / \mathrm{kg}$ and 
$\alpha$-tocopherol varied in the range of 78.4-452 $\mathrm{mg} / \mathrm{kg}$. In addition to these forms, $\delta$-tocopherol, $\gamma$-tocopherol and $\delta$-tocotrienol were also detected in the range of $27.2-56.2 \mathrm{mg} / \mathrm{kg}, 5.8-89.3 \mathrm{mg} / \mathrm{kg}$ and $12.3-25.8 \mathrm{mg} / \mathrm{kg}$, respectively, in all samples. Among individual vitamin E homologues (Heinemann et al., 2008), $\alpha$-tocopherol, $\alpha$-tocotrienol, and $\gamma$-tocotrienol were the most aboundant components in japonica rice, while in indica rice, the highest mean level was for $\gamma$-tocotrienol, followed by $\alpha$-tocopherol and $\alpha$-tocotrienol. Tocochromanol composition was in good agreement with the tocopherol composition of several grape seed oils reported in the literature (Wie et al., 2009; Demirtas et al., 2013). With a few exceptions, the percentage of tocotrienols was significantly $(P<0.05)$ higher in the HMRB than in the WMRB. Therefore, tocotrienols could be present more in the outer bran layer, while tocopherols would be distributed more in the interior layer. The main vitamin $\mathrm{E}$ homologue was the $\alpha$ - or $\gamma$-isomer among tocopherols or tocotrienols.

Table 1. Tocol composition of colored rice bran cultivars (mg/kg lipid)*

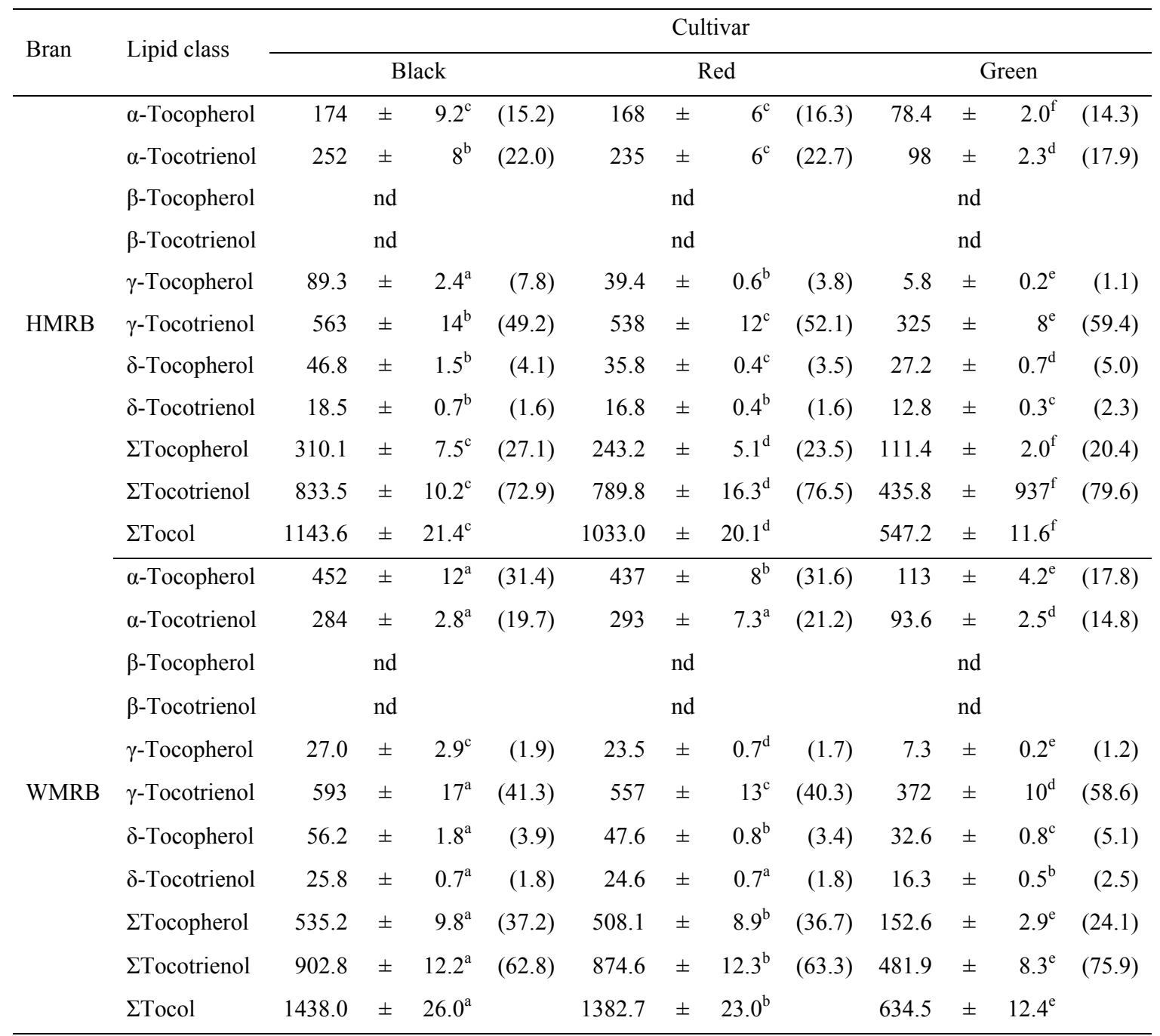

HMRB: half-milled rice brans. WMRB: well-milled rice brans. nd: (not detectable) $<0.01 \mathrm{mg} / \mathrm{kg}$.

* Mean values \pm standard error. Each value represents the average of three determinations, and is expressed as $\mathrm{mg} / \mathrm{kg}$ lipid. Values in parentheses are relative $\mathrm{wt} \%$ contents of the individual tocopherols in HMRB or WMRB. Values in the same row with different superscripts are significantly different between the individual cultivars $(P$ $<0.05)$.

Vitamin $E$ is represented by $\alpha-, \beta-, \gamma-$, and $\delta$-tocopherols, and $\alpha-, \beta-, \gamma$ - and $\delta$-tocotrienols, all of which occur in nature, and 14 vitamins are theoretically possible (Bramley et al., 2000). Vitamin $\mathrm{E}$ is a term frequently used to designate a family of related compounds, namely, tocopherols and tocotrienols (Amaral et al., 2005), which are important lipophilic antioxidants with essential effects in living system against aging (Agostinucci et al., 2002) 
and reducing the risk of cancer (Lee et al., 2000). However, $\alpha$-tocopherol is regarded as the most active and predominant form (Bender \& Mayes, 2003). Tocotrienols have been indicated to suppress the effects of reactive oxygen species more effectively than tocopherols, and different studies of in vitro and in vivo effects suggest that tocotrienols may lower cholesterol levels and suppress tumor growth (Schaffer, Muller, \& Eckert, 2005). Published data related to the tocopherol and tocotrienol content of these colored rice bran lipids is lacking and comparison is not currently possible.

\subsection{Lipid Compositions in the Rice Bran Cultivars}

Profiles of lipid components were compared among the HMRB and WMRB from the three cultivars (Table 2). Dominant components were TAG (HMRB: 78.4-81.2\%; WMRB: 78.0-81.6\%), followed by FFA (HMRB: 6.7-7.6\%; WMRB: 5.6-8.8\%) and PL (HMRB: 6.3-6.8\%; WMRB: 6.5-7.0\%), accompanied by very small amounts (0.4-2.3\%) of other lipid components. When comparing the nine lipid components of the HMRB and WMRB among all three cultivars, the percentage of TAG was significantly $(P<0.05)$ lower in the green cultivar than that in the black or red cultivar, while the percentage of FFA was significantly $(P<0.05)$ higher in the green cultivar than that in the black cultivar. However, with a few exceptions, no substantial differences $(P>0.05)$ in the contents of the lipid components were observed between the values estimated by a combination analysis of TLC and GC using the internal standard (C15:0).

Presumably, the minor components, such as FFA, 1,3- and 1,2-diacylglycerols or monoacylglycerols, may be formed by the partial enzymatic hydrolysis of reserve TAG during the storage of the rice seeds (Aboul-Nasr, Ramadan, \& El-Dengawy, 1997). The lipid components resulting from 'fat by hydrolysis' in starch granules were determined, showing the presence of FFA with lysolecithin and lysoglycolipids (Okunishi \& Ohtsubo, 2008).

Table 2. Lipid components obtained from colored rice bran cultivars*

\begin{tabular}{|c|c|c|c|c|c|c|c|c|c|c|c|c|c|}
\hline \multirow{2}{*}{ Bran } & \multirow{3}{*}{$\begin{array}{l}\text { Lipid class } \\
\text { Hydrocarbons }\end{array}$} & \multicolumn{12}{|c|}{ Cultivar } \\
\hline & & \multicolumn{4}{|c|}{ Black } & \multicolumn{4}{|c|}{ Red } & \multicolumn{4}{|c|}{ Green } \\
\hline \multirow{9}{*}{ HMRB } & & 29.7 & \pm & $0.7^{\mathrm{c}}$ & $(0.4)$ & 21.5 & \pm & $0.5^{\mathrm{d}}$ & $(0.4)$ & 19.2 & \pm & $0.4^{\mathrm{d}}$ & $(0.4)$ \\
\hline & Steryl esters & 74.2 & \pm & $1.8^{\mathrm{c}}$ & (1.0) & 64.6 & \pm & $1.6^{\mathrm{d}}$ & (1.2) & 52.7 & \pm & $1.3^{\mathrm{e}}$ & (1.1) \\
\hline & Triacylglycerols & 5999 & \pm & $40^{\mathrm{d}}$ & (80.7) & 4374 & \pm & $39^{\mathrm{e}}$ & $(81.2)$ & 3752 & \pm & $38^{\mathrm{f}}$ & (78.4) \\
\hline & Unknown & 59.3 & \pm & $1.4^{\mathrm{b}}$ & $(0.8)$ & 26.9 & \pm & $0.7^{\mathrm{d}}$ & $(0.5)$ & 24.0 & \pm & $0.5^{\mathrm{e}}$ & $(0.5)$ \\
\hline & Free fatty acids & 497 & \pm & $12^{\mathrm{c}}$ & (6.7) & 399 & \pm & $10^{\mathrm{d}}$ & (7.4) & 364 & \pm & $9^{\mathrm{e}}$ & (7.6) \\
\hline & 1, 3-Diacylglycerols & 118.7 & \pm & $2.9^{\mathrm{b}}$ & (1.6) & 70.0 & \pm & $1.7^{\mathrm{e}}$ & (1.3) & 110.2 & \pm & $2.8^{\mathrm{b}}$ & (2.3) \\
\hline & 1, 2-Diacylglycerols & 111.2 & \pm & $2.7^{\mathrm{c}}$ & (1.5) & 64.6 & \pm & $1.6^{\mathrm{e}}$ & (1.2) & 63.9 & \pm & $1.5^{\mathrm{e}}$ & (1.3) \\
\hline & Monoacylglycerols & 66.7 & \pm & $1.6^{\mathrm{d}}$ & $(0.9)$ & 26.9 & \pm & $0.7^{\mathrm{e}}$ & $(0.5)$ & 76.7 & \pm & $1.8^{\mathrm{c}}$ & (1.6) \\
\hline & Phospholipids & 475 & \pm & $11^{\mathrm{d}}$ & (6.4) & 339 & \pm & $8.5^{\mathrm{e}}$ & (6.3) & 326 & \pm & $8.2^{\mathrm{e}}$ & (6.8) \\
\hline \multirow{9}{*}{ WMRB } & Hydrocarbons & 77.3 & \pm & $1.9^{\mathrm{a}}$ & $(0.7)$ & 71.5 & \pm & $1.7^{\mathrm{a}}$ & $(0.8)$ & 39.4 & \pm & $1.0^{\mathrm{b}}$ & $(0.5)$ \\
\hline & Steryl esters & 154.6 & \pm & $3.8^{\mathrm{a}}$ & (1.4) & 89.4 & \pm & $2.3^{\mathrm{b}}$ & $(1.0)$ & 141.7 & \pm & $3.5^{\mathrm{a}}$ & $(1.8)$ \\
\hline & Triacylglycerols & 8968 & \pm & $65^{\mathrm{a}}$ & $(81.2)$ & 7276 & \pm & $48^{\mathrm{b}}$ & (81.6) & 6124 & \pm & $42^{\mathrm{c}}$ & (78.0) \\
\hline & Unknown & 44.2 & \pm & $1.1^{\mathrm{c}}$ & $(0.4)$ & 71.5 & \pm & $1.8^{\mathrm{a}}$ & $(0.8)$ & 23.6 & \pm & $0.6^{\mathrm{f}}$ & $(0.3)$ \\
\hline & Free fatty acids & 619 & \pm & $15^{\mathrm{b}}$ & (5.6) & 500 & \pm & $12^{\mathrm{c}}$ & (5.6) & 693 & \pm & $16^{\mathrm{a}}$ & (8.8) \\
\hline & 1, 3-Diacylglycerols & 176.7 & \pm & $4.3^{\mathrm{a}}$ & (1.5) & 98.3 & \pm & $2.4^{\mathrm{c}}$ & (1.1) & 78.7 & \pm & $1.9^{\mathrm{d}}$ & (1.0) \\
\hline & 1, 2-Diacylglycerols & 154.6 & \pm & $3.8^{\mathrm{a}}$ & (1.4) & 134.1 & \pm & $3.4^{\mathrm{b}}$ & (1.5) & 78.7 & \pm & $2.0^{\mathrm{d}}$ & $(1.0)$ \\
\hline & Monoacylglycerols & 88.4 & \pm & $2.2^{\mathrm{b}}$ & $(0.8)$ & 98.3 & \pm & $2.5^{\mathrm{b}}$ & (1.1) & 141.7 & \pm & $3.5^{\mathrm{a}}$ & $(1.8)$ \\
\hline & Phospholipids & 773 & \pm & $19^{\mathrm{a}}$ & (7.0) & 581 & \pm & $14^{\mathrm{b}}$ & $(6.5)$ & 535 & \pm & $13^{\mathrm{c}}$ & $(6.8)$ \\
\hline
\end{tabular}

HMRB: half-milled rice brans. WMRB: well-milled rice brans.

* Mean values \pm standard error. Each value represents the average of three determinations, and is expressed as $\mathrm{mg}$ lipid class per $500 \mathrm{~g}$ of rice. Values in the same row with different superscripts are significantly different between the individual cultivars $(P<0.05)$. Values in parentheses are relative wt\% contents of the individual lipids in the total lipids. 


\subsection{Fatty Acid Composition of Major Lipids in the Rice Bran Cultivars}

Fatty acid compositions of total lipids, TAG, FFA and PL in the rice bran lipids were compared among the HMRB and WMRB of the three cultivars (Table 3). The distribution of total unsaturated fatty acids, particularly linoleic (18:2n-6) and oleic (18:1n-9) acids, which accounted for 77.2-79.3\% (total lipids), 77.9-79.9\% (TAG), 70.8-73.5\% (FFA) and 71.6-76.1\% (PL), respectively. These patterns were very similar within total lipids, TAG, FFA or PL among the HMRB and WMRB from all threee cultivars. However, some differences $(P<0.05)$ in fatty acid composition were noted when comparing the four lipid classes (total lipids, TAG, FFA and PL) as shown in Table 3. The percentage of palmitic $(16: 0)$ acid was significantly $(P<0.05)$ higher in the FFA (24.1-26.2\%) and PL (21.8-25.4\%) than that in the total lipids (18.3-19.3\%) and TAG (17.1-19.5\%) among all three cultivars. With a few exceptions for the green rice cultivar (total, TAG and PL) in both brans, the percentage of oleic $(18: 1 n-9)$ acid was significantly $(P<0.05)$ higher in the black and red bran lipids than in the green bran lipids for the four lipid classes. On the other hand, with a few exceptions of FFA for the HMRB and WMRB, the percentage of linoleic $(18: 2 \mathrm{n}-6)$ acid was significantly $(P<0.05)$ higher in the green rice bran than in the black or red rice bran for total lipids, TAG and PL fractions. It has been demonstrated that there exists distinct differences between nonoglutinous and glutinous types of cereals in lipid content and fatty acid composition (Fujino \& Mano, 1972; Taira, 1984; Taira \& Lee, 1988). These fatty acid composition for the black and red rice brans (nongulutinous) are very similar to the results observed for rice bran lipids in the cultivars: Koshihikari, Haenuki, Akitakomachi, Hitomibore and Sasanishiki reported in a previous paper (Yoshida et al., 2011). The data for fatty acid distribution of minor lipid components (steryl esters, 1,3- and 1,2-diacylglycerols or monoacylglycerols) in Table 2, were not included in Table 3 because these lipid components were present in too low concentrations to provide reliable results for their fatty acid compositions.

Table 3. Fatty acid distribution of major lipid components obtained from colored rice bran cultivars*

\begin{tabular}{|c|c|c|c|c|c|c|c|c|c|}
\hline \multirow[t]{2}{*}{ Bran } & \multirow{2}{*}{$\begin{array}{l}\text { Lipid } \\
\text { class }\end{array}$} & \multirow[t]{2}{*}{ Cultivar } & \multicolumn{6}{|c|}{ Fatty acid (wt\%) } & \multirow[t]{2}{*}{$\begin{array}{r}\text { Total } \\
\text { USFA } \\
\end{array}$} \\
\hline & & & $16: 0$ & 18:0 & $18: 1$ & $18: 2$ & $18: 3$ & Others & \\
\hline \multirow{12}{*}{ HMRB } & \multirow[t]{3}{*}{ Total } & Black & $19.4 \pm 1.0^{\mathrm{a}}$ & $1.6 \pm 0.1^{b}$ & $43.2 \pm 1.3^{\mathrm{a}}$ & $33.2 \pm 1.1^{\mathrm{b}}$ & $1.4 \pm 0.1^{\mathrm{a}}$ & $1.2 \pm 0.1^{\mathrm{b}}$ & $78.0^{\mathrm{a}}$ \\
\hline & & Red & $19.3 \pm 1.0^{\mathrm{a}}$ & $2.4 \pm 0.1^{\mathrm{a}}$ & $40.1 \pm 1.2^{\mathrm{b}}$ & $35.2 \pm 1.2^{\mathrm{b}}$ & $1.5 \pm 0.1^{\mathrm{a}}$ & $1.5 \pm 0.1^{\mathrm{a}}$ & $77.2^{\mathrm{a}}$ \\
\hline & & Green & $19.3 \pm 1.0^{\mathrm{a}}$ & $1.6 \pm 0.1^{\mathrm{b}}$ & $36.1 \pm 1.2^{\mathrm{c}}$ & $40.5 \pm 1.3^{\mathrm{a}}$ & $1.5 \pm 0.1^{\mathrm{a}}$ & $1.0 \pm 0.1^{\mathrm{b}}$ & $78.3^{\mathrm{a}}$ \\
\hline & \multirow[t]{3}{*}{ TAG } & Black & $18.3 \pm 0.8^{\mathrm{b}}$ & $1.7 \pm 0.1^{\mathrm{d}}$ & $46.1 \pm 2.1^{\mathrm{a}}$ & $31.5 \pm 1.2^{\mathrm{d}}$ & $1.2 \pm 0.1^{\mathrm{b}}$ & $1.0 \pm 0.1^{\mathrm{b}}$ & $79.0^{\mathrm{a}}$ \\
\hline & & Red & $17.3 \pm 0.7^{\mathrm{b}}$ & $1.8 \pm 0.1^{\mathrm{b}}$ & $43.5 \pm 2.0^{\mathrm{b}}$ & $34.9 \pm 1.3^{\mathrm{c}}$ & $1.3 \pm 0.1^{\mathrm{b}}$ & $1.2 \pm 0.1^{\mathrm{a}}$ & $79.8^{\mathrm{a}}$ \\
\hline & & Green & $19.3 \pm 0.8^{\mathrm{a}}$ & $1.6 \pm 0.1^{\mathrm{b}}$ & $35.1 \pm 1.2^{\mathrm{c}}$ & $41.5 \pm 1.5^{\mathrm{a}}$ & $1.5 \pm 0.1^{\mathrm{a}}$ & $1.0 \pm 0.1^{\mathrm{b}}$ & $79.0^{\mathrm{a}}$ \\
\hline & \multirow[t]{3}{*}{ FFA } & Black & $25.2 \pm 1.0^{\mathrm{b}}$ & $2.7 \pm 0.1^{\mathrm{a}}$ & $41.5 \pm 2.1^{\mathrm{c}}$ & $28.7 \pm 1.0^{\mathrm{a}}$ & $1.2 \pm 0.1^{\mathrm{c}}$ & $0.7 \pm 0.1^{\mathrm{c}}$ & $71.6^{\mathrm{b}}$ \\
\hline & & Red & $24.1 \pm 1.0^{\mathrm{b}}$ & $1.9 \pm 0.1^{\mathrm{a}}$ & $44.9 \pm 2.2^{\mathrm{a}}$ & $27.8 \pm 1.1^{\mathrm{a}}$ & $0.6 \pm 0.1^{\mathrm{d}}$ & $0.7 \pm 0.1^{\mathrm{c}}$ & $73.5^{\mathrm{a}}$ \\
\hline & & Green & $26.1 \pm 1.1^{\mathrm{a}}$ & $1.8 \pm 0.1^{\mathrm{c}}$ & $43.8 \pm 2.1^{\mathrm{a}}$ & $25.4 \pm 1.3^{\mathrm{c}}$ & $1.6 \pm 0.1^{\mathrm{b}}$ & $1.3 \pm 0.1^{\mathrm{b}}$ & $70.9^{\mathrm{b}}$ \\
\hline & \multirow[t]{3}{*}{ PL } & Black & $22.3 \pm 1.0^{\mathrm{b}}$ & $1.3 \pm 0.1^{\mathrm{a}}$ & $38.6 \pm 1.3^{b}$ & $34.6 \pm 1.3^{\mathrm{c}}$ & $1.5 \pm 0.1^{\mathrm{a}}$ & $1.7 \pm 0.1^{\mathrm{a}}$ & $74.9^{\mathrm{b}}$ \\
\hline & & Red & $23.1 \pm 1.0^{\mathrm{b}}$ & $1.1 \pm 0.1^{\mathrm{a}}$ & $38.9 \pm 1.2^{\mathrm{b}}$ & $34.7 \pm 1.3^{\mathrm{c}}$ & $1.5 \pm 0.1^{\mathrm{a}}$ & $0.7 \pm 0.1^{\mathrm{c}}$ & $75.4^{\mathrm{a}}$ \\
\hline & & Green & $25.4 \pm 1.1^{\mathrm{a}}$ & $0.8 \pm 0.1^{\mathrm{c}}$ & $29.9 \pm 1.2^{\mathrm{d}}$ & $41.8 \pm 1.8^{\mathrm{a}}$ & $1.3 \pm 0.1^{\mathrm{b}}$ & $0.8 \pm 0.1^{\mathrm{c}}$ & $73.2^{\mathrm{b}}$ \\
\hline \multirow{12}{*}{ WMRB } & \multirow[t]{3}{*}{ Total } & Black & $18.4 \pm 0.8^{\mathrm{a}}$ & $1.6 \pm 0.1^{b}$ & $43.3 \pm 1.7^{\mathrm{a}}$ & $34.2 \pm 1.2^{\mathrm{b}}$ & $1.3 \pm 0.1^{\mathrm{b}}$ & $1.2 \pm 0.1^{\mathrm{b}}$ & $78.8^{\mathrm{a}}$ \\
\hline & & Red & $18.3 \pm 0.8^{\mathrm{a}}$ & $1.4 \pm 0.1^{\mathrm{c}}$ & $42.5 \pm 2.0^{\mathrm{a}}$ & $35.3 \pm 1.2^{\mathrm{b}}$ & $1.2 \pm 0.1^{\mathrm{b}}$ & $1.3 \pm 0.1^{\mathrm{b}}$ & $79.3^{\mathrm{a}}$ \\
\hline & & Green & $19.3 \pm 1.0^{\mathrm{a}}$ & $1.6 \pm 0.1^{b}$ & $36.1 \pm 1.2^{\mathrm{c}}$ & $40.5 \pm 2.0^{\mathrm{a}}$ & $1.5 \pm 0.1^{\mathrm{a}}$ & $1.0 \pm 0.1^{\mathrm{b}}$ & $78.3^{\mathrm{a}}$ \\
\hline & \multirow[t]{3}{*}{ TAG } & Black & $18.5 \pm 0.8^{\mathrm{b}}$ & $1.7 \pm 0.1^{b}$ & $46.1 \pm 2.0^{\mathrm{a}}$ & $31.5 \pm 1.2^{\mathrm{d}}$ & $1.2 \pm 0.1^{\mathrm{b}}$ & $1.0 \pm 0.1^{\mathrm{b}}$ & $79.0^{\mathrm{a}}$ \\
\hline & & Red & $17.1 \pm 0.8^{\mathrm{b}}$ & $2.0 \pm 0.1^{\mathrm{a}}$ & $43.5 \pm 2.0^{\mathrm{b}}$ & $34.9 \pm 1.2^{\mathrm{c}}$ & $1.3 \pm 0.1^{\mathrm{b}}$ & $1.2 \pm 0.1^{\mathrm{a}}$ & $79.9^{\mathrm{a}}$ \\
\hline & & Green & $19.5 \pm 1.2^{\mathrm{a}}$ & $1.6 \pm 0.1^{\mathrm{b}}$ & $37.0 \pm 1.3^{\mathrm{c}}$ & $39.3 \pm 1.4^{\mathrm{b}}$ & $1.4 \pm 0.1^{\mathrm{a}}$ & $1.2 \pm 0.1^{\mathrm{a}}$ & $77.9^{\mathrm{b}}$ \\
\hline & \multirow[t]{3}{*}{ FFA } & Black & $25.3 \pm 1.0^{\mathrm{b}}$ & $2.2 \pm 0.1^{b}$ & $42.4 \pm 1.5^{b}$ & $26.7 \pm 1.2^{\mathrm{b}}$ & $1.8 \pm 0.1^{\mathrm{a}}$ & $1.6 \pm 0.1^{\mathrm{a}}$ & $71.4^{\mathrm{b}}$ \\
\hline & & Red & $25.5 \pm 1.0^{\mathrm{b}}$ & $1.6 \pm 0.1^{\mathrm{c}}$ & $43.6 \pm 1.5^{\mathrm{a}}$ & $26.8 \pm 1.2^{\mathrm{b}}$ & $1.1 \pm 0.1^{\mathrm{c}}$ & $1.4 \pm 0.1^{b}$ & $71.8^{\mathrm{b}}$ \\
\hline & & Green & $26.2 \pm 1.0^{\mathrm{a}}$ & $2.1 \pm 0.1^{b}$ & $40.9 \pm 1.3^{c}$ & $28.6 \pm 1.2^{\mathrm{a}}$ & $1.0 \pm 0.1^{\mathrm{c}}$ & $1.2 \pm 0.1^{\mathrm{b}}$ & $70.8^{\mathrm{b}}$ \\
\hline & \multirow[t]{3}{*}{ PL } & Black & $21.8 \pm 1.0^{\mathrm{c}}$ & $1.3 \pm 0.1^{\mathrm{a}}$ & $40.7 \pm 1.3^{\mathrm{a}}$ & $33.7 \pm 1.2^{\mathrm{c}}$ & $1.2 \pm 0.1^{\mathrm{b}}$ & $1.3 \pm 0.1^{\mathrm{b}}$ & $76.1^{\mathrm{a}}$ \\
\hline & & Red & $23.3 \pm 1.1^{\mathrm{b}}$ & $1.3 \pm 0.1^{\mathrm{a}}$ & $39.2 \pm 1.3^{b}$ & $34.0 \pm 1.3^{\mathrm{c}}$ & $1.2 \pm 0.1^{\mathrm{b}}$ & $1.0 \pm 0.1^{\mathrm{b}}$ & $74.7^{\mathrm{b}}$ \\
\hline & & Green & $25.4 \pm 1.1^{\mathrm{a}}$ & $1.3 \pm 0.1^{\mathrm{b}}$ & $32.1 \pm 1.2^{\mathrm{c}}$ & $38.2 \pm 1.4^{\mathrm{b}}$ & $1.3 \pm 0.1^{\mathrm{b}}$ & $1.7 \pm 0.1^{\mathrm{a}}$ & $71.6^{\mathrm{c}}$ \\
\hline
\end{tabular}

HMRB: half-milled rice brans. WMRB: well-milled rice brans. USFA: Unsaturated fatty acids.

* Mean values \pm standard error. Each value represents the average of three determinations, and is expressed the relative $\mathrm{wt} \%$ contents of the individual fatty acids. Values in the same column with different superscript are significantly different between the individual cultivars $(P<0.05)$. "Others" include minor fatty acids such as C14:0, C16:1, C20:0 and C22:0. 


\subsection{Distribution of TAG Molecular Species}

The carbon number (TCN) denotes the total legth of the three acyl-chain present in the TAG. For example, 54 are predominantly composed of 18:0, 18:1, 18:2 and 18:3. These TCN within TAG obtained from the three rice bran cultivars ranged from 48 to 56 as listed in Figure 1. Each value is the mean of triplicate determinations and is expressed as milligram lipid per $20 \mathrm{~g}$ brans. Dominant components were $52(41.3-42.6 \%)$ and 54 (47.5-48.6\%) TAG, followed by small amounts of $50(9.5-10.2 \%), 56(0.2-0.3 \%)$ and $48(0.2-0.3 \%)$ TAG, respectively.

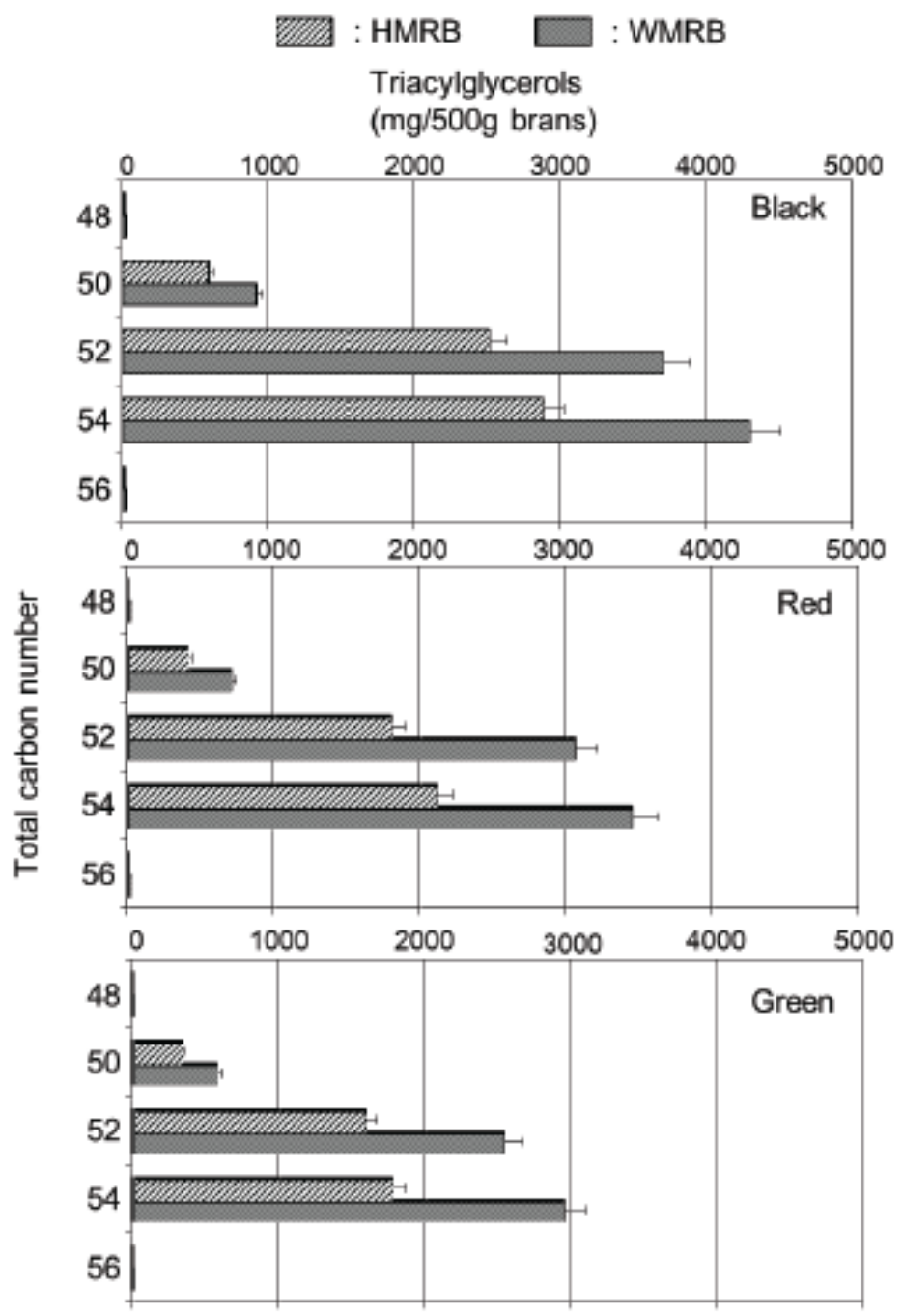

Figure 1. Content of TAG prepared from colored rice bran cultivars. Each value represents the average of three replicates. Horizontal bars depict the mean and standard deviation of three determinations 


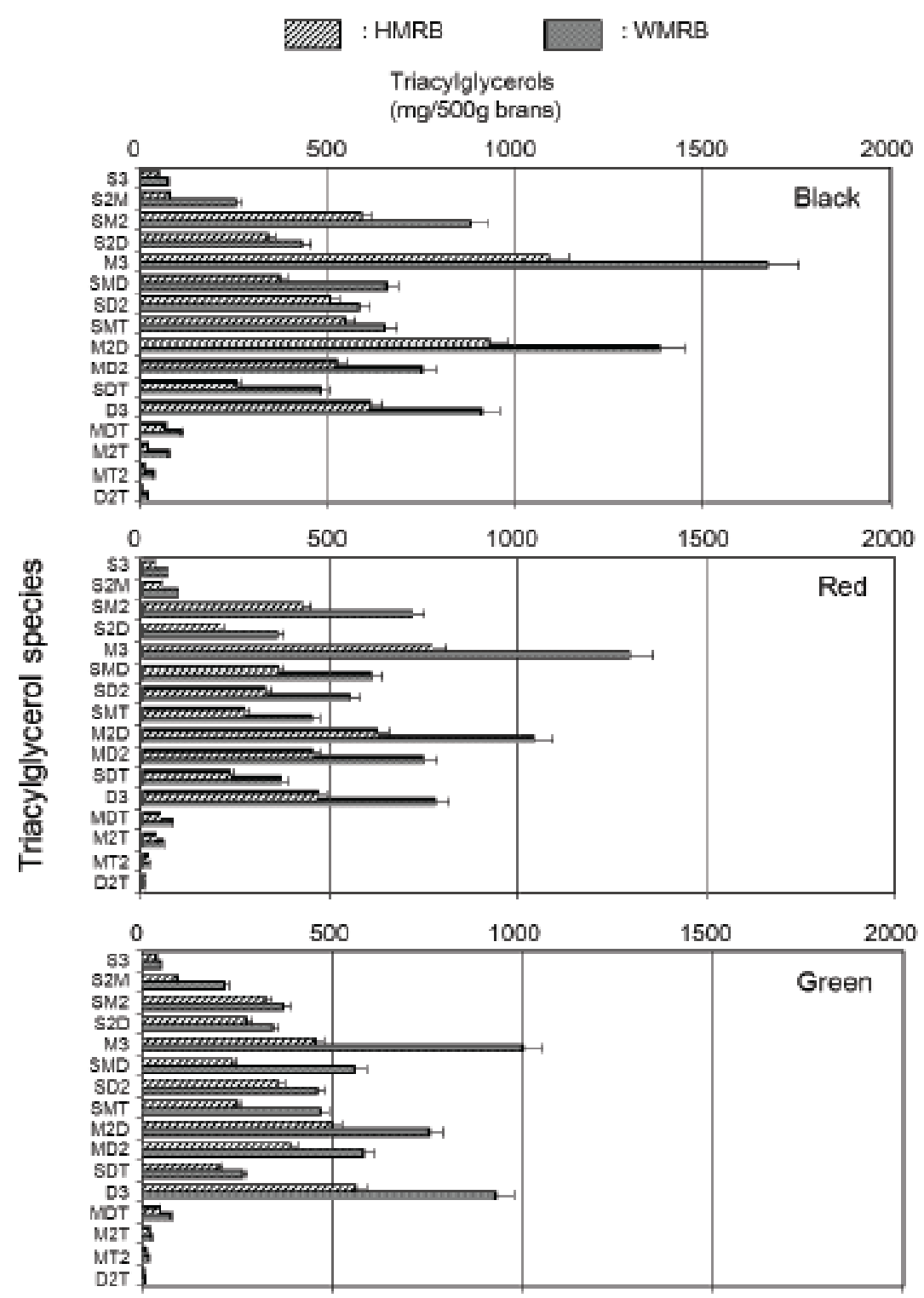

Figure 2. Characteristics of the major molecular species of TAG isolated from colored rice bran cultivars

Saturated FA (S) consists of myristic (14:0), palmitic (16:0), stearic (18:0) and arachidic (20:0) acids. Unsaturated FA, palmitoleic (16:1), oleic (18:1n-9), linoleic (18:2n-6) and $\alpha$-linolenic (18:3n-3), are denoted as monoene (M), diene (D) and triene (T), respectively. Horizontal bars depict the mean and standard deviation of three determinations.

The distribution patterns of the individual TAG molecular species are shown in Figure 2. Sixteen different molecular species were detected among the TAG isolated from these rice bran lipids. These species were arranged according to the degree of unsatiration on the acyl-chain length of TAG (from top to bottom in Figure 2, respectively). In the three cultivars, the major TAG molecular species were $\mathrm{SM}_{2}$ (POO or $\left.\mathrm{StOO}\right), \mathrm{S}_{2} \mathrm{D}$ ( $\mathrm{PPL}$ or PStL or StStL), $\mathrm{M}_{3}(\mathrm{OOO}), \mathrm{SMD}$ (POL or StOL), $\mathrm{SD}_{2}$ (PLL or StLL), SMT (POL or StOL), $\mathrm{M}_{2} \mathrm{D}(\mathrm{OOL}), \mathrm{MD}_{2}$ (OLL), SDT (PLLn or StLLn) and $\mathrm{D}_{3}$ (LLL) in the three cultivars. On the other hand, the other species ( $\mathrm{S}_{3}$; PPP or PPSt or StStSt, $\mathrm{S}_{2} \mathrm{M}$; PPO or PStO or StStO, MDT; OLLn, $\mathrm{M}_{2} \mathrm{~T} ;$ OOLn, $\mathrm{MT}_{2}$; OLnLn and $\mathrm{D}_{2} \mathrm{~T}$; LLLn) were minor components (less than 3.5\%). However, the three-letter designation does not demonstrate regioselective positional isomers of fatty acyl in the TAG: P, palmitic (16:0), St, stearic (18:0), O, oleic (18:1n-9); L, linoleic (18:2n-6); Ln, $\alpha$-linolenic (18:3n-3) fatty acid moieties. Thus, these distribution patterns in the molecular species of TAG were very similar to each other among the HMRB and WMRB for from the three cultivars. 


\section{Conclusions}

The predominant components were $\gamma$-tocotrienol, $\alpha$-tocopherol, and $\alpha$-tocotrienol with much smaller amounts of $\gamma$ - and $\delta$-tocopherols, and $\delta$-tocotrienol. Major lipid components in three different Japanese colored rice bran cultivars were TAG, FFA, and PL, while other components were also present in minor proportions. Sixteen molecular species of TAG were identified in these rice brans. The main components were palmitodiolein or stearodiolein (6.1-9.8\%), triolein (16.4-18.7\%), palmitoleolinolein or stearoleolinolein (6.3-9.2\%), palmitodilinolein or stearodilinolein (6.5-9.5\%), palmitoleolinolenin or stearoleolinolenin (6.2-9.2\%), dioleolinolein (12.3-15.5\%), oleodilinolein $(8.4-10.4 \%)$ and trilinolein $(10.2-15.2 \%)$. To the best of our knowledge this is the first report of the TAG composition of colored rice bran cultivars. In general, the distribution patterns were not significantly different $(P>0.05)$ among the HMRB and WMRB from the three cultivars, suggesting similar TAG molecular species and tocochromanol compositions. Currently, the consumer awareness of health food poducts is increasing and food scientists have been searching for interesting sources of healthul natural components. The results showed that rice bran extracts contain large amounts of nutraceticals with proven positive health effects (Ha et al., 2006).

\section{Acknowledgments}

We thank Prof. Bruce Holub of the Department of Human Health and Nutritional Sciences, University of Guelph, Canada, for reviewing and commenting on this manuscript. Financial support for part of this study was provided by a Grant-in-Aid for Special Assistance for Working Expenses of the Private University and Cooperative Research Center of Life Science ('Academic Frontier’ Project, 2010-2013).

\section{References}

Aboul-Nasr, M. H., Ramadan, B. R., \& El-Dengawy, R. A. (1997). Chemical composition of pumpkin seeds. Journal of Agriculture Science, 28, 163-172.

Agostinucci, K., Manfredi, T. G., Cosmas, A., Martin, K., Han, S. N., Wu, D., ... Meydani, M. (2002). Vitamin $\mathrm{E}$ and age alter liver mitochondrial morphometry. Journal Anti-Aging Medicine, 5, 173-178. http://dx.doi.org/10.1089/10945450260195612

Amaral, J. S., Casal, S., Torres, D., Seabra, R. M., \& Oliveira, B. P. P. (2005). Simultaneous determination of tocopherols and tocotrienols in hazelnuts by a normal phase liquid chromatographic method. Analytical Sciences, 21, 1545-1548. http://dx.doi.org/10.2116/analsci.21/1545

Bender, D. A., \& Mayes, P. A. (2003). Vitamins and minerals. Harper's illustrated Biochemistry (26th ed). Lange Medical Books/Mc Graw-Hill: New York, pp. 451-498 in chapter 45.

Bilyk, A., Piazza, G. J., Bistline, R. G. Jr., \& Haas, M. J. (1991). Separation of cholesterol, and fatty acylglycerols, acid and amides by thin-layer chromatography, Lipids, 26, 405-406. http://dx.doi.org/10.1007/BF02537208

Bramley, P. M., Elmadfa, I., Kafatos, A., Kelly, F. J., Manios, Y., Roxborough, H. E., ... Wanger, K. H. (2000). "Vitamin E," Journal of the Science and Food Agriculture, 80, 913-938. http://dx.doi.org/10.1002/(SICI)1097-0010(20000515)80:7<913::AID-JSFA600>3.3.CO;2-V

Champagne, E. T., Marshall, W. E., \& Goynes, W. R. (1990). Effect of degree milling and lipid removal on starch gelatinization in the brown rice kernel. Cereal Chemistry, 67, 570-574.

Demirtas, I., Pelvan, E., Özdemir, I. S., Alasalvar, C., \& Ertas, E. (2013). Lipid characteristics and phenolics of native grape seed oils grown in Turkey. European Journal of Lipid Science and Technology, 115, 641-647. http://dx.doi.org/10.1002/ejlt.201200159

Folch, J., Lee, M., \& Sloane-Stanley, G. H. (1957). A simple method for the isolation and purification of total lipids from animal tissues. The Journal of Biological Chemistry, 226, 497-509.

Fujino, Y., \& Mano, Y. (1972). Classification of lipids and composition of fatty acids in brown rice. Eiyo to Shokuryo, 25, 472-474. http://dx.doi.org/10.4327/jsnfs1949.25.472

Ha, T. -Y., Ko, S. -N., Lee, S, -M., Kim, H. -R., Chung, S. -H., Kim, S. -K., ... Kim, L. -H. (2006). Changes in nutraceutical lipid components of rice at different degree of milling. European Journal of Lipid Science and Technology, 108, 175-181. http://dx.doi 10.1002/ejlt.200500250

Heinemann, R. J. B., Xu, Z., Godber, J. S., \& Lanfer-Marquez. (2008). Tocopherols, tocotrienols, and $\gamma$-oryzanol contents in japonicas and indica subspecies of rice (Oryza sativa L.) cultivated in Brazil. Cereal Chemistry, 85, 243-247. http:// dx.doi.org/10.1094/CCHEM-85-2-0243 
Itani, T., \& Ogawa, M. (2004). History and recent trends of red rice in Japan. Japanese Journal of Crop Science, 73, 137-147. http://dx.doi.org/10.1626/jcs.73.137

Itoh, N., Masuo, Y., Yoshida, Y., Cynshi, O., Jishage, K., \& Niki, E. (2006). $\gamma$-Tocopherol attenuates MPTP-induced dopaime loss more efficiently than $\alpha$-tocopherol in mouse brain. Neuroscience Letters, 403, 136-140. http://dx.doi.org/10.1016/j.neulet.2006.04.028

Jennings, B. H., \& Akoh, C. A. (2009). Effectiveness of natural versus synthetic antioxidants in a rice bran oil-based structured lipid. Food Chemistry, 114, 1456-1461. http://dx.doi.org/10.1016/j.foodchem.2008.11.031

Jham, G. N., Velikova, R., Nikolova-Damyavova, B., Rabelo, S. C., Silva, J. C. T., ... Cecon, P. R. (2005). Preparative silver ion TLC/RP-HPLC determination of coffee triacylglycerol molecular species. Food Research International, 38, 121-126. http://dx.doi.org/10.106/j.foodres.2004.07.010

Kitts, D. D., Huynh, M. D., Hu, C., \& Trites, A. W. (2004). Season variation in nutrient composition of Alaskan walleye pollock. Canadian Journal of Zoology, 82, 1408-1415. http://dx.doi.org/10.1139/z04-116

Lee, C. Y. J., \& Wan, J. M. F. (2000). Vitamin E supplementation improves cell-mediated immunity and oxidative stress of Asian men and women. Journal of Nutrition, 130, 2932-2937.

Marshall, W. E., Norman, F. L., \& Goynes, W. R. (1990). Effect of lipid and protein removal on starch gelatinization in whole gram milled rice. Cereal Chemistry, 67, 458-463.

Molkentin, J. (2007). Detection of foreign fat in milk fat from different continents by triacylglycerol analysis. European Journal of Lipid Science and Technology, 109, 505-510. http://dx.doi.org/10.1002/ejlt.200600286

Morris, M. C., Evans, D. A., Tangney, C. C., Bienias, J. L., Wilson, R. S., Aggarwal, N. T., \& Scherr, P. A. (2005). Relation of the tocopherol forms to incident Alzheimer disease and to cognitive change. American Journal of Clinical Nutrition, 81, 508-514. http://dx.doi.org/10.3945

Oki, T., Masuda, M., Kobayashi, M., Nishida, Y., Furuta, S., Suda, I., \& Sato, T. (2002). Polymeric procyanidins as radical-scavenging components in red-hulled rice. Journal of Agricultural and Food Chemistry, 50, 7524-7529. http://dx.doi.org/10.1021/jf025841z

Okunishi, T., \& Ohtsubo, K. (2008). Lipid derivatives in brown rice for various storage and suppression methods. Nippon Shokuhin Kagaku Kogaku Kaishi, 55, 76-77. http://dx.doi.org/10.3136/nskkk.55.76

Perdon, A. A., Siebenmorgen, T. J., Mauromoustakos, A., Griffin, V. K., \& Johnson, E. R. (2001). Degree of milling effects on rice pasting properties. Cereal Chemistry, 78, 205-209. http://dx.doi.org/10.1094/CCHEM.2001.78.2.205

Przybylski, R., Klenspirt-Pawlik, D., Anwar, F., \& Rudzinski, M. (2009). Lipid components of north American wild rice (Zizania palustris). Journal of the American Oil Chemists' Society, 86, 553-559. http://dx.doi.org/10.1007/s1746-009-1383-6

Saleh, M. I., \& Meullenet, J. F. (2007). Effect of moisture content at harvest and degree of milling (based on surface lipid content) on the texture properties of cooked long-grain rice. Cereal Chemistry, 84, 119-124. http://dx.doi.org/10.1094/CCHEM-84-2-0119

Schaffer, S., Muller, W. E., \& Eckert, G. P. (2005). Tocotrienol: Constitutional effects in aging and disease. Journal of Nutrition, 135, 151-154. http://dx.doi.org/10.3945

Siebenmorgan, T. J., Matsler, A. L., \& Earp, C. F. (2006). Milling characteristics of rice cultivars and hybrids. Cereal Chemistry, 83, 69-172.

Sugano, M., \& Tsuji, E. (1997). Rice bran oil and cholesterol metabolism. Journal of Nutrition, 127, 521-524.

Taira, H. (1984). Lipid content and fatty acid composition of nonoglutinous and glutinous varieties of foxtail millet. Journal of Agricultural and Food Chemistry, 32, 369-371. http://dx.doi.org/10.1021/jf00122a047

Taira, H., Nakagahra, M., \& Nagamine, T. (1988). Fatty acid composition of indica, sinica, javanica, and japonica groups of nonglutinous brown rice. Journal of Agricultural and Food Chemistry, 36, 45-47. http://dx.doi.org/10.1021/jf00079a011

Wie, M., Sung, J., Choi, Y., Kim, Y., Jeong, H. S., \& Lee, J. (2009). Tocopherols and tocotrienols in grape seeds from 14 cultivars grown in Korea. European Journal of Lipid Science and Technology, 111, 1255-1258. http://dx.doi.org/10.1002/ejlt.200900058

Wilson, T. A., Nicolosi, R. J., Woolfrey, B., \& Kritchevsky, D. (2007). Rice bran oil and oryzanol reduce plasma 
lipid and lipoprotein cholesterol concentrations and aortic cholesterol ester accumulation to a greater extent than ferulic acid in hypercholesterolemic hamsters. Journal of Nutritional Biochemistry, 18, 105-112. http://dx.doi.org/10.1016/j.jnutbio.2006.03.006

Yadav, B. K., \& Jindal, V. K. (2001). Monitoring milling quality of rice by image analysis. Computers and Electronics in Agriculture, 33, 19-33.

Yoshida, H., Tomiyama, Y., \& Mizushina, Y. (2010). Tocopherol distributions and triacylglycerol molecular species in broad beans (Vicia faba). Food Science and Technology Research, 16, 409-416. http://dx.doi.org/10.3136/fstr.16.409

Yoshida, H., Tanigawa, T., Kuriyama, I., Yoshida, N., Tomiyama, Y., \& Mizushina, Y. (2011). Variation in fatty acid distribution of different acyl lipids in rice (Oryza sativa L.) brans. Nutrients, 3, 505-514. http://dx.doi/10.3390/nu3040505

Yoshida, H., Yoshida, N., Kuriyama, I., Tomiyama-Sakamoto, Y., \& Mizushina, Y. (2013). Profiles of lipid components, fatty acid distributions of triacylglycerols and phospholipids in Jack beans (Canavalia gladiata DC). Food Chemistry, 136, 807-812. http://dx.doi.org/10.1016/j.foodchem.2012.08.087

Zhou, Z., Robards, K., Helliwell, S., \& Blanchard, C. (2002a). Composition and functional properties of rice. International Journal of Food Science and Technology, 37, 849-868. http://dx.doi.org/10.1111/ijfs.12288

Zhou, Z., Robards, K., Helliwell, S., \& Blanchard, C. (2002b). Ageing of stored rice: Changes in chemical and physical attributes. Journal of Cereal Science, 35, 65-78. http://dx.doi.org/10.1016/j.jcs.2013.02.003

\section{Copyrights}

Copyright for this article is retained by the author(s), with first publication rights granted to the journal.

This is an open-access article distributed under the terms and conditions of the Creative Commons Attribution license (http://creativecommons.org/licenses/by/3.0/). 